\title{
Participatory Education Research: An Exploration of Ways to Enhance Children's Rights Through Ensuring Respect For All Cultures And Religions
}

\begin{tabular}{|c|c|}
\hline \multicolumn{2}{|c|}{ School of Social and Policy Studies, Flinders University, Adelaide, Australia } \\
\hline Article history & In the global context, we cannot talk about orphanages in isolation \\
\hline $\begin{array}{l}\text { Received: } \\
01.03 .2015\end{array}$ & $\begin{array}{l}\text { without talking about their cultural backgrounds and religious } \\
\text { affiliations. Orphanages and religious institutions are so closely }\end{array}$ \\
\hline $\begin{array}{l}\text { Received in revised form: } \\
20.06 .2015\end{array}$ & $\begin{array}{l}\text { related to each other in every context. This paper is based on } \\
\text { participatory action research (PAR) which involved policy makers }\end{array}$ \\
\hline & and service providers to explore ways to enhance children's rights \\
\hline & $\begin{array}{l}\text { through ensuring respect for all religions. The historical } \\
\text { perspectives and the social economic and environmental issues }\end{array}$ \\
\hline Key words: & have caused many children to become orphaned / abandoned / \\
\hline $\begin{array}{l}\text { Orphanages, participatory } \\
\text { action research, children's } \\
\text { rights, children's homes, } \\
\text { multiculturalism, capabilities } \\
\text { approach. }\end{array}$ & $\begin{array}{l}\text { destitute and they rely on care provided in children's homes. In } \\
\text { many cases these homes have taken no account of their cultural } \\
\text { backgrounds or their religious affiliations. As a result, many } \\
\text { children's homes host and facilitate care for children of different } \\
\text { faiths and diverse cultures within the same institution. Thus, it is } \\
\text { inevitable that this complex and multifaceted array of orphanage } \\
\text { environment raises many governance issues in terms of different } \\
\text { religious perspectives. It is this background that has stressed the } \\
\text { necessity of PAR on multiculturalism to address these governance } \\
\text { issues in children's homes. This would involve responding properly } \\
\text { to governance issues, which have sustained inconsistencies } \\
\text { regarding religious beliefs in terms of children's rights and their } \\
\text { spiritual needs. The paper introduces the capabilities approach in } \\
\text { relation to the way in which religious traditions need to foster and } \\
\text { protect the human rights of children. }\end{array}$ \\
\hline
\end{tabular}

\section{Introduction}

This paper focuses on human rights of institutionalized children in terms of religious perspectives. It explores ways to enhance children's rights through ensuring respect for all cultures and religions. The paper is based on participatory action research (PAR) which involved policy makers and service providers as research respondents to investigate policy implications and governance practices of children's homes throughout Sri Lanka. All commissioners of the provincial Departments of Probation and Child Care Services (DPCCS)

\footnotetext{
"Correspondence: loku0004@flinders.edu.au; eshanthaariyadasa@gmail.com
} 
were interviewed to ascertain their role in the policy making process. Thirty managers from different children's homes were interviewed concerning their service provision. The recruitment of these groups as participants for the study was based on the aim of using their feedback to produce a set of guidelines for the process of policy making and governance of children's homes. These children's homes are institutional care settings provided for orphaned, abandoned and destitute children by Non-Government Organizations (DPCCS, 2010). Findings of the PAR 2012 demonstrate that children's homes and religious institutions are closely related to each other and religions play a major role in the governance aspect of children's homes. However, it has also been identified that religious rights and multicultural needs of the institutionalized children have often been poorly addressed.

This paper addresses the demographic patterns in terms of different provinces in Sri Lanka as it becomes vital when exploring ways to enhance children's rights through ensuring respect for all cultures and religions. The paper then discusses religious perspectives on children and their rights in broader aspects in terms of the Universal Declaration of Human Rights (UDHR) and the United Nations Convention on the Rights of the Child (UNCRC). It emphasises the influence of religion on the evolution of children's homes and governance practices within these. Subsequently, the paper discusses the need to understand multiculturalism (Sarah, 2014) within children's homes in terms of different religious perspectives. Particular emphasis is put on the practical public education example identified during the PAR 2012 which has been demonstrated in a children's home.

This paper advocates for an approach which would involve responding properly to multicultural issues which have sustained inconsistencies regarding religious beliefs in terms of children's rights and their spiritual needs. The paper identifies the Capabilities Approach (Nussbaum, 2011) as a mechanism to support addressing children's rights in children's homes within multicultural settings. The section on the role of religion and human capabilities, discusses how a capabilities approach incorporates different religious perspectives and how it maintains its position as a common ground to address religious rights. The discussion section emphasises the significance of the incorporation of religious perspectives in the governance aspect of children's homes in terms of addressing children's rights and their needs. Finally, the paper makes recommendations on governance practices of children's homes in terms of different religious perspectives.

\section{Demographic patterns in terms of different provinces}

The significance for 'exploration of ways to enhance children's rights through ensuring respect for all cultures and religions' become evident when studying the demographic patterns in terms of different provinces in Sri Lanka.

Sri Lankan society is an ethno-religious mosaic and within the ethnic groups, there are clear religious divisions as well (Tamil Guardian, 2014). Of the ethnic and religious groups, the majority of Sri Lanka's population are Sinhalese Buddhists and predominate in all parts of the country except the Northern and Eastern Provinces. The Tamil Hindu minority lives primarily in the north and east, while the Muslim minority lives largely in the east (War Child, 2014), but generally are scattered throughout the country. The Eastern Province is an ethnically mixed area where Tamils, Muslims and Sinhalese are found in sizeable numbers even though Tamils have a slightly higher statistical edge. Indian Tamils, the descendants of labourers brought from Southern India by the British in the 19th century to work on tea and coffee estates, are concentrated in parts of the Central, Uwa and Sabaragamuwa provinces. Sinhalese 
and Tamil Christians maintain a significant presence in the coastal areas as a result of over 500 years of constant European colonial presence and the consequent Christianisation of significant numbers of the population in these areas. However, Christians can be found in all parts of the country in small numbers. Malays are mostly concentrated in and around the city of Colombo (Ariyadasa \& McIntyre-Mills, 2014a).

\section{Religious perspectives on children and their rights in terms of the UDHR and the UNCRC}

The UDHR (United Nations, 1948) states that everyone has the right to freedom of thought, conscience and religion. Nussbaum (2000a, p. 180) identifies this in stating "Religion is so important to people, such a major source of identity". She argues that religious capabilities must be respected, but equally, that capabilities which are sometimes suppressed by religions must also be respected. The UDHR (United Nations, 1948) has also given a special position to children and emphasises that children are entitled to special care and assistance. Recognising this, the UNCRC is the globally accepted literature that guides many countries in the process of protecting the human rights of children (United Nations, 1989). The UNCRC respects the rights and duties of parents in providing religious and moral guidance to their children. Religious groups around the world have expressed support for the UNCRC, which indicates that it in no way prevents parents from bringing their children up within a religious tradition (UNICEF, 2015). Article 14 of the UNCRC decrees that children have the right to think and believe what they want and to practice their religion. At the same time, it recognizes that as children mature and are able to form their own views, some may question certain religious practices or cultural traditions. The UNCRC supports a child's right to examine their beliefs, but it also states that their right to express their beliefs implies respect for the rights and freedom of others. Many articles of the UNCRC manifest the key elements of many religions with regard to child protection. This is unsurprising as the UNCRC is an outcome of the efforts of many individuals and organisations representing many religious and ethnic backgrounds.

The following religious perspectives demonstrate the important position of a child within diverse religious teachings. In Buddhist teachings "children are the greatest treasure of mankind and the first and foremost teachers of the child are his/her parents" (Sobitha, 2006, p. 228). Hindus believe that "the children are humanity's greatest assets" (Ranganathananda, 2006, p. 210). The Quran highlights that "children are a trust and a child is a gift from God and a trust placed in the care of the child's elders" (Shukri, 2006, p. 219). Christianity teaches "one cannot enter into the kingdom of heaven unless one cultivates the qualities of a child" (Fernando, 2006, p. 231). Lababidy (1996, p. 7) summarises the situation:

The notion of children as 'spiritual beings' is common to most of the world's religions, and has been portrayed in such popular figures as the young Krishna, Siddhartha, and the baby Jesus. Indeed, in many religions the archetype of spiritual purity is symbolized by the innocent child. This perception of the child as innocent and vulnerable is a common motivating factor influencing contemporary religious organizations to focus the application of their spiritual practice on supporting children in difficult circumstances as an ultimate value.

The creation and growth of orphanages/children's homes that are managed by different religious organizations can be identified as an outcome of the perception of the child as innocent and vulnerable. The UNCRC has taken this into account and Article 20 states that "children who cannot be looked after by their own family have a right to special care and must be looked after properly, by people who respect their ethnic group, religion, culture and 
language" (UNICEF, 2015, p. 5). Furthermore, the religious influence upon the governance aspects of children's homes reflects the special position given to vulnerable children in different religious beliefs.

\section{The influence of religion on the growth and the governance of children's homes}

The teachings from the Bible and the verses of the Holy Quran have undoubtedly influenced the growth of children's homes for orphans and destitute children. Through such religious teachings, people tend to accept orphans as a special group of children influencing religious institutions with respect to responding to the needs of orphans through building children's homes. Thus, the influence of religion on the governance aspects of children's homes cannot be underestimated.

There are religious traditions that bring both positive and negative impacts to governance aspects of children's homes. The religious tradition of dane (Ariyadasa, 2015), the giving of alms, performed by Buddhists and Hindus has both positive and negative characteristics. Dane has been a powerful source of protection for institutionalised children's rights, by elevating their well-being in many aspects such as diet, health and provision of basic needs (Ariyadasa, 2015, pp. 61-62). A negative aspect of this tradition, according to the policy makers and policy officers is that the public sees these institutionalized children as helpless and welfare cases (ibid). Ariyadasa explains this paradox by stating that "There is a real danger that children may come to believe that this is their fate - to be fed and supported by others and they have to live with it. This makes them more vulnerable as it does not encourage them to develop their own potential and stand with a positive attitude to confront the challenges in their lives". He adds that according to policy makers dane consumes vital time that can be utilized for the future prospects of the charges of the home in many aspects. "After the meal donation, children have to sing songs and dance as a sign of gratitude for the generous thoughts of the public. Most of the times, while the public is around, children have to sacrifice their evening rest, recreational activities, school homework and sometimes most important extra classes" (cited in Ariyadasa 2015 p. 61). The Islamic concept of kafala (Marsoof, 2007) has influenced the policy and practice of children's homes and has been included in several paragraphs of the United Nations Guidelines for the Alternative Care of Children (referred to here after as the 'UN Guidelines').

These examples: the support of orphans as espoused through the Christian Bible (Bible Hub, 2014) and the Holy Quran (Marsoof, 2007); the tradition of dane by Buddhists and Hindus to children's homes (Ariyadasa, 2015); and kafala within Islamic law demonstrate how religious perspectives have impacted upon the birth, growth, governance and policy implementation upon children's homes.

The internationally recognized instrument of children's rights that accommodate governance practices of children's homes is the UN Guidelines (United Nations, 2010). The implementation of the UN Guidelines has been largely influenced by religious perspectives. These guidelines emphasise that in the determination of appropriate care countries must: pay attention to promoting and safeguarding the right to freedom of religion or belief; pay due respect to gender and religion differences; implement effective measures to prevent a child's separation from his/her family with support from religious organisations; plan for care provisions considering the desirability of the child remaining within his/her cultural, linguistic and religious background; investigate the cultural and religious practices regarding the provision of alternative care and assure the cultural, social, gender and religious sensitization 
of the child. It also emphasises that countries must not provide alternative care with a prime purpose of furthering the religious goals of the providers, and must not persuade a child to change religion or belief during a care placement (United Nations, 2010).

The prescribed UN Guidelines imply that alternative care provision should match the child's religion or belief. However, in the current circumstances it is not difficult to find children's homes that care for children from different religious faiths by management of diverse religious backgrounds. Thus, the existing environments of children's homes challenge the policies that are indicated in the UN Guidelines. The background for this situation is not coincidental.

\section{The historical perspectives of 'orphanages' in Sri Lanka}

Since the acceptance of Buddhism; the monarchy, the religion, and the society were so inter-connected and inter-dependent, that the role played by the Buddhist monks became crucial to sustain the system (Gamage, 2015).

During the British colonization of Sri Lanka, from 1815 to 1948, the Christian influence created an opportunity for building and managing orphanages. However, the majority of Sri Lankans were Buddhists and the remainder were of the Hindu and Islamic faith. Thus, the running of the orphanages by the management of a faith which was different to that of most children and the community was challenging. Most of these homes had little contact with society in general and the connections to birth families were minimal.

In-depth interviews held with commissioners' of the DPCCSs by the author indicate that at the time orphanage culture began in Sri Lanka, contraventions in terms of children's rights had neither been considered nor documented in treaties. However, during the era of British colonization, the religious leaders in Sri Lanka, particularly the Buddhist monks, who headed the communities informally, considered orphanage culture as a threat to Buddhist society. This was because these orphanages were placed in missions supervised by Christian organizations and the children in these orphanages had been converted to Christianity. Not all children in these homes were orphans. Extended families with many children put them in the care of these institutions as a measure to address their poverty issues.

Offering one's own child to a Buddhist temple is not a new practice for Buddhist communities. Before the establishment of the present day school structures, during the colonisation periods, the education of children had been delivered by the Buddhist monks in their monasteries. There was at least one temple in every village. Parents sent their children to these temples to learn how to read, write and understand the teachings of Buddhism. Gross (1996, p. 88) explains that in traditional Buddhist countries, monasteries often served as important educational institutions. In the Sri Lankan context, according to Gamage (2015), a revolutionary change in education came with the acceptance of the Buddha's idea that every person whether a man or a woman had a right to be educated. Gamage adds that important temples established schools, which came to be known as monasteries or pirivenas for higher level education. During the teaching and training processes, the chief incumbent of the temple would identify the best students and request the parents' permission for them to be accepted into the temple for the betterment of Buddhism and for its dissemination. The parents recognized this as a great honour for the children and themselves. Therefore, they had no hesitation in offering their children to the temple and their inheritance to the chief monk. This tradition has continued for centuries since the introduction of Buddhism to Sri Lanka around $300 \mathrm{BC}$ and continues in some parts of the country. 
During the extensive Portuguese, Dutch and British colonisation period from 1505 to 1948, many lowland Buddhists and Hindus were forced to convert to Christianity and the coastal Moors suffered religious persecution and were forced to retreat to the central highlands (Pereira, 2007; Roberts, 2004; Wicremasekera, 2004) . As a result, the Buddhist monastery structure was replaced by the Christian missionary structure. The churches did not find it difficult to keep the best students in their missions and to educate and train them in the values of Christianity. As it was in the Buddhist culture, Christian parents accepted it as a great honour to have one of their children become a priest. It is because, although these parents started practicing Christianity as a result of colonisation, they still retained the Buddhist traditions.

According to the provincial commissioners of DPCCSs, in those days, church orphanages were received with goodwill by the community as they relieved the pressures of raising disadvantaged and destitute children. Priests also found that orphanages acted as a means to fit into a new community and bring attention to the Christian faith. However, for Buddhist monks, Christian intervention was a threat to long-standing traditions dominated by their beliefs. Thus, the monks addressed this situation by creating a series of homes named Asarana Sarana Lama Niwasa (shelters for destitute children). Gross (1996) adds that Buddhist monasteries also served as orphanages or places for parents to deposit children when they had too many. In both situations, when churches or temples enrolled children in their orphanages or homes for destitute children, the interests of the children were largely ignored. Cultural attitudes driven by strong religious beliefs gave the adults discretionary powers to make decisions concerning the children.

The orphanage culture established by the Christian churches ultimately influenced and encouraged communities of different beliefs to initiate their own orphanages. Thus, Buddhist and Hindu temples provided facilities to commence Buddhist and Hindu children's homes and Islamic mosques began to raise Muslim orphans in Islamic children's homes. The PAR 2012 findings indicate that around $25 \%$ of all children's homes are still overseen by Christian churches despite the fact that the charges therein are from many non-Christian backgrounds. Similarly, Tamil children of Hindu faith are found in children's homes managed by Buddhist temples and vice versa with no access for such children to attend to their particular religious beliefs. In these situations, children's beliefs usually flow with the majority of the children and/or in accordance with the religious belief of whoever is providing the children's home. This context clearly demonstrates that the multicultural environment within and outside children's homes has a historical perspective that is strongly influenced by the period of colonisation.

\section{Multiculturalism and children's homes}

It is clear that the formation of Christian orphanages housing non-Christian children and the subsequent formation of such children's homes by other religious faiths was an important feature of an increasingly multicultural country.

The social, economic and environmental effect has caused many children to become orphaned, abandoned and/or destitute and they rely on care provided in children's homes. According to Ariyadasa (2013), a variety of causes, such as poverty and the necessity for mothers to work abroad as well as family breakdown (Thambiah 2012a, 2012b), offending and abuse (Save the Children 2005) have been associated with the high reliance on the provision of alternative (institutional) care for children. The Sri Lankan civil war that lasted 
for nearly three decades was an outcome of social and cultural issues that prevailed among diverse ethnic groups of different religious affiliations (Ariyadasa \& McIntyre-Mills, 2014a, 2014b). The war caused thousands of children to be admitted into children's homes. Women often work as domestic labourers in the Middle-Eastern countries to address the issue of household poverty and over $30 \%$ of children's institutionalization has been due to the overseas employment of mothers (Ariyadasa, 2015). The tsunami, a decade ago, and the recent loss of life due to landslides, elephant attacks and floods has produced many thousands of children who have been deprived of parental care. In many cases these homes have taken no account of their cultural backgrounds or religious affiliations. As a result, many children's homes host and facilitate the care of children of different faiths and diverse cultures within the same institution.

The financial facilitators and caregivers of children's homes have strong links to local and international organizations that have different social, cultural and religious backgrounds. Above all, the policy guidelines on the governance of these homes are literally based on the UN Guidelines (United Nations, 2010). This is an intellectual outcome from the contributions of many individuals and organizations of different religions and distinctly cultured backgrounds. Thus, it is inevitable that this complex and multifaceted array of orphanage environments raises many governance issues in terms of different religious perspectives. With the intention of national unity and religious harmony, it would be best if the $\mathrm{VCH}$ management could accommodate children irrespective of their cultural identity, religious affiliation and ethnic backgrounds. However, the practical issues when addressing children's needs in terms of language and religious rights, as explained in UN guidelines paragraph 6 (UN 2010, p. 14), undermine such intentions (Ariyadasa \& McIntyre-Mills, 2014a). Thus it has highlighted a need to understand multiculturalism within children's homes.

This paper explores ways to enhance children's rights by ensuring respect for all religions and paying due attention to multiculturalism. This would involve responding properly to governance issues which have sustained inconsistencies regarding religious beliefs in terms of children's rights and their spiritual needs. The management team of a children's home has maintained the values of multiculturalism by incorporating shrines of many religions into their religious observance space (Fig. 1). This simple gesture has manifested many things and is discussed below as it educates other homes that systems thinking and systemic approaches help identify strategies to address children's rights and needs. 


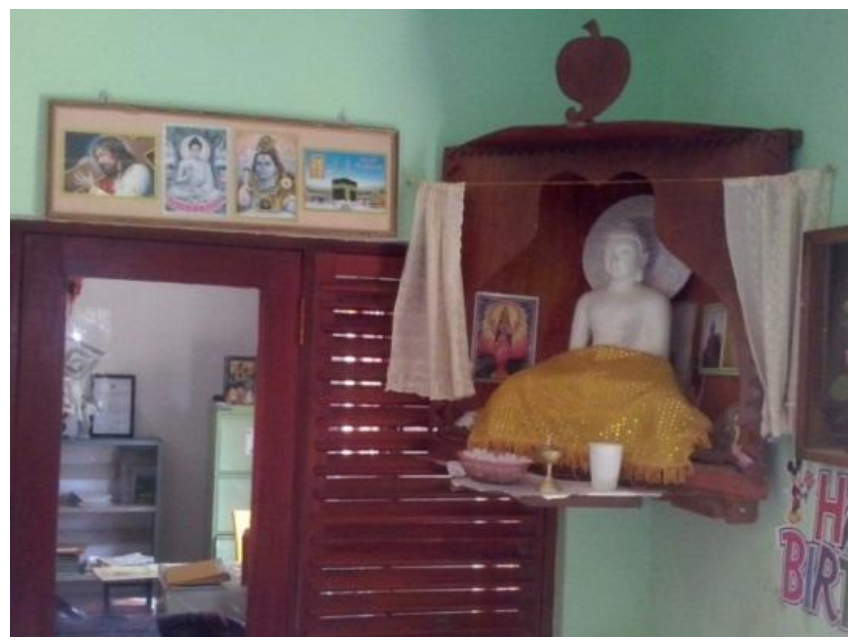

Figure 1: The religious observance space represents all the four major religion beliefs in Sri Lanka (source: PAR 2012)

\section{Practical public education example: Integration of multicultural values into institutional care settings}

The following account of a manager from a children's home explains the complex situation of an institutional care environment where children of varying ethnic backgrounds have to practice different religious beliefs that challenge their linguistic backgrounds, prompting issues of cultural identity. It also identifies the prompt actions that this home has taken to address the issues of multicultural needs within the institutional care setting. This home encourages children to see the relevance of multiple religions on a daily basis, and enhances their capabilities to live a multicultural world.

My children's home is situated in a small village where most of the villagers are Sinhalese Buddhists. Therefore, the Department of Probation and Child Care Services recognize mine as a home mainly for Sinhalese Buddhist children although it is not intended for a particular race or a religion. We have 18 children. Of them, 16 are Sinhalese Buddhists by birth and the other two are Muslims by birth. These two girls who are sisters have no parents or known relatives. When they were placed in our home they were aged 8 and 6 . Prior to the transfer, they had been raised in another children's home which was managed at a Buddhist Temple since they were 3 and 5 years old. They are well versed in the Sinhalese language and Buddhist traditions as they had been brought up within a Sinhalese Buddhist community. Thus, we have not found any issues related to language or religion when nurturing them in our home. The fact that these two children had been brought up within a Sinhalese Buddhist community, they were characterized as such. However, when they were addressed by their names, anybody would know them as Muslims, because their names are common Muslim names. Although their names are of Muslim origin, these two girls hesitate to identify themselves as Muslims. The reason for this is that, they do not behave as a typical Muslim girl would. In Sri Lanka, Muslims generally speak the Tamil language. These girls know no Tamil and have not had any experiences of observing the Islamic religion.

We have never forced them to learn Sinhalese nor have they been forced to observe the Buddhism. However, for an outsider, it may look as if we have insisted on them becoming Sinhalese Buddhists. When they were asked whether they wanted to practice Islam, they had no answer, because they knew nothing about Islam and saw no reason why they should observe a religion that they have never practiced. Interestingly, until I asked them such a question, they thought that they were Sinhalese Buddhists. Thus, it is only their names that identify them as Muslims. In all other ways they are Sinhalese Buddhists. 
In our home, we have provided our children with every facility to practice Buddhism. If we had children from other religions, we would have facilitated them to practice their religions as well. However, we have never disregarded other religions. At the religious observing corner, we have kept the pictures of Jesus Christ, Lord Shiva and the picture of Mecca in addition to the Lord Buddha's shrine to symbolize the four major religions practiced all over in Sri Lanka. This showcases and convinces the charges and the public how much we respect the other religions and how much we really care for the devotees from other religions. Our children's home is funded by many individuals and organizations that represent different ethnicities and diverse religious backgrounds. Therefore, our religious corner pleases anyone from other religious affiliations and gives them an identity in our home and everyone feels as part of our own family (Interview with a children's home manager, PAR 2012).

It does represent the four major religions practiced in Sri Lanka and symbolizes religious harmony (Fig. 2). The other 26 homes that I visited during fieldwork also had religious observing spaces. In contrast, they were all confined to the major religion for which the children's home was originally intended. Some children who were raised under a different religion before coming into these homes had to observe the prevailing religion in the homes or to refrain from observing their personal religious beliefs. Lababidy $(1996$, p. 6) regrets such situations and states "Unfortunately, many children's programs in developed and developing countries are still designed with little thought to cultural or religious diversity even though the importance of culture is highlighted in articles within the Convention".

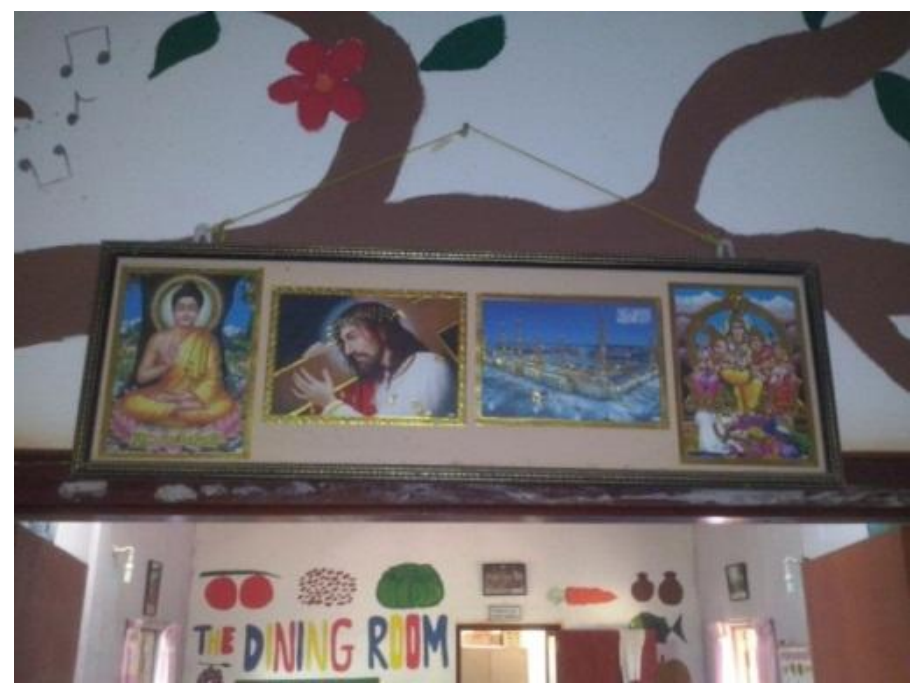

Figure 2: Symbolic representations of the four major religions practiced by the majority of the Sri Lankans have been displayed above the entrance to the dining room (source: PAR 2012).

The example of the manager who has placed symbols to represent all other religions in his home not only gives respect to all children from diverse cultural backgrounds and different religious affiliations, but also pays respect to visitors and donors who support the home. This manager summarised his perspective as a Buddhist "The one who pays respect to his own religion, pays respect to other religions and the one who pays no respect to other religions, pays no respect to his own". This manager's example can be regarded as good governance practice and a body of thought that manifests the proper way to respond to cultural and religious diversity. 


\section{Need for an approach that supports implementing children's rights in multicultural environments}

Some of the traditional practices in religions may contravene to the UNCRC. It may not be ethical to criticize a tradition which has its roots embedded in the history. However, everyone has to admit that in less than four years since its inception, more than 170 nations, or close to $99 \%$ of the global community, have accepted the convention as an internationally agreed minimum standard for the treatment of children (Cook, 1996). In the UNCRC there is no room for a caste system or gender based discrimination. Any religion that worships God/s accepts that God/s is/are just and good. Thus, no one can expect God/s to justify the caste system or to compromise gender based discrimination. Nussbaum (2000b) comments that conduct of these traditions are egregiously bad and must be a form of human error, which can be remedied while leaving religion itself intact.

It is clear that the tendency for Sri Lankan children's homes having multicultural environments is strong. Furthermore, they demonstrate that these multicultural environments have created human rights issues in terms of religious perspectives. The provisions of the UN Guidelines have directed service providers in addressing issues pertaining to a child's right to a religion or belief and his/her right to practice a religion. These guidelines are helpful when the service providers and the service users belong to a homogeneous religion. For example, the tradition of the Islamic faith to not consume pork or pork related food and the Hindu tradition of not consuming beef or beef based food presents issues within a multicultural environment. If all belong to one faith, it is possible to maintain their religious traditions consistently. However, where individuals from different faiths are present, some degree of compromise is necessary. A Buddhist or Hindu management team may encourage the prevention of meat consumption, but a Christian within that environment may not share such a concern. Whilst the right to eat meat in this environment ought to be respected, this conflicts with the right of children of other faiths to not be associated with such a practice. An acknowledgement of these conflicts needs to be made and an appropriate compromise found. The UN Guidelines (United Nations, 2010, p. 14) emphasise that "Carers should ensure that children receive adequate amounts of wholesome and nutritious food in accordance with local dietary habits and relevant dietary standards, as well with the children's religious beliefs". Thus, to be in line with the UN Guidelines when providing meals, the children from a multicultural institutional care environment need to be attended to on a case-by-case basis considering the best interest of child in terms of dietary habits and standards, and religious beliefs.

One commissioner's narration about an incident relevant to a children's home of Buddhist children, provides another example related to multicultural issues within a children's home (interview with a commissioner, 2012). This particular home had been managed by a foreign NGO. The management team had introduced a poultry and pig farm as vocational training for the children as well as a measure to meet the financial constraints of the home. However, the people around the home who were mostly Buddhists did not tolerate this management style. The DPCCS received a number of petitions from the villagers opposing the managers' role that included killing animals, a practice that is at odds with Buddhist traditions. DPCCS was obliged to request that manager discontinue any vocational training that involved killing animals or selling animals for meat. According to this commissioner, the manager did not positively respond to the Department's request and the home soon closed. The provision of vocational training to children of institutional care is encouraged by UN Guidelines. The paragraph 135 (United Nations, 2010, p. 19) states "Ongoing educational and vocational training opportunities should be imparted as part of life skills education to young people". 
However, this incident reveals that the neglect of religious perspectives when providing vocational training in a multicultural setting can lead to the termination of institutional care for needy children. This indicates the significance of an approach that values multiculturalism and supports addressing children's rights issues in similar environments.

\section{Capabilities Approach as a leverage to support addressing the child rights issues in children's homes of multicultural settings}

The capabilities approach has been recognized by many social scientists and economists as a human development approach. The core themes of the PAR on which this paper is based are closely related to the capabilities approach (CA) of Nussbaum (2011). These core themes that are listed as re-integration, health, safety, formal education, informal education and vocational training are an outcome of the findings of the PAR (Fig. 3). These findings have been analysed in terms of the children's rights outlined in the UN Guidelines. Thus it is meaningful to determine whether the children's rights issues with respect to multicultural environments of children's homes could be addressed using the CA.

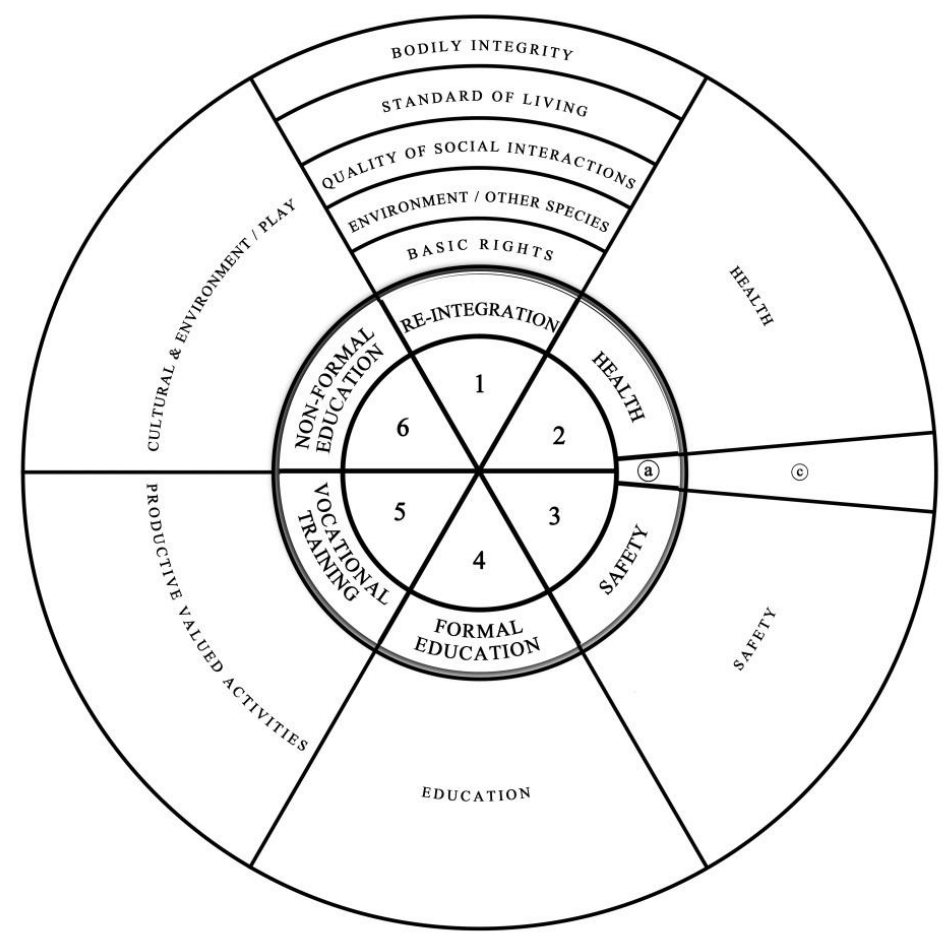

Figure 3: Comparative analysis of the key axial themes of the PAR against Nussbaum's central capabilities (a: core themes, b: central capabilities)

Ariyadasa and McIntyre-Mills (2014a, p. 24) confirms that "Provision of institutional care alone as an alternative to children's denied rights is never going to address their multifaceted issues in social, cultural, economic, political and environmental contexts" . They emphasise that children are denied their rights, often because their re-integration process is not efficient and effective (ibid). Thus, improving the efficiency and effectiveness of the re-integration process will contribute significantly to addressing the human rights issues faced by institutionalized children. In this PAR re-integration is referred to as a child's reunification with family/natural birth environment, socialization with society/community or other permanent care solutions such as local/foreign adoption (Ariyadasa \& McIntyre-Mills 2014a). 
The core theme; re-integration represents five capabilities of Nussbaum's approach (Figure 3 ). Through the responses of policy makers and service providers, it has been identified that institutionalization denies children the right to enjoy; bodily integrity, standard of living, quality of social interactions, environment and basic rights, in varying degrees. Thus, to achieve these capabilities and to restore the rights of the children, they need to be reintegrated. The UN Guidelines (United Nations, 2010, p. 18) also emphasise that the objective of residential care should be to provide temporary care and to contribute actively to the child's family reintegration or, to secure their stable care in an alternative family setting. Ariyadasa and McIntyre-Mills (2014b) have provided evidence for re-integrating institutionalized children in line with the capabilities approach identified by Nussbaum. They also state that this leads to an efficient and effective process improving the human rights situation and advocates for the standard of care the children receive during their institutionalization. Thus, the capabilities approach supports addressing the child rights issues in children's homes within multicultural settings. This finding promotes the significance of educating the public on the role of religion and human capabilities.

\section{Role of religion and human capabilities}

Religion is quite well integrated in institutional care environments. All thirty children's homes that were included in the PAR 2012 had religious observance spaces in their premises. This was common to many children's homes, irrespective of their religious background. In nine homes, religious observances were instituted when beginning and ending the day. Provincial commissioners for childcare services have emphasised the importance of the incorporation of religious practices in children's homes. They state that observing religion, on a daily basis exemplifies good practice as it reminds the children of good manners, ethical conduct and disciplined life (Interviews with commissioners, PAR 2012).

One probation officer had collected the thoughts of the children on the amount of time taken for religion observance in their homes. He comments that:

In some homes, in the point of views of children, the matrons and wardens had spent unnecessary time on religious practices daily that had absorbed too much of the children's time. Caregivers had not considered children's age, their interests and preferences. Some elder children commented that they regularly spend nearly an hour on religious observances. For younger children it is worse, as they are so tired that they fall asleep and are sent to bed without having completed homework or even having eaten dinner (Interview with a probation officer, PAR 2012).

This probation officer adds that the caregivers should be mindful about their charges' varying capacities and interests when implementing religious practices. It should not be just a conventional practice that has been a tradition for many years but flexible enough to enhance children's evolving capacities to make a sensible and balanced citizen.

"The major religions are all, at their heart, concerned with the conduct of life, and all the major traditions can plausibly be seen as attempts to reform or improve the conduct of life" (Nawaz 1993 cited in Nussbaum, 2000a, p. 190). Nussbaum sees this as the role that religions play in transmitting and fostering moral views on the conduct of life. She argues that while religion concerns many other things such as faith and ritual practice and celebration and pleasure and contemplation, at least a part of its concern is moral. Thus they must respect the plurality and diversity of voices in each religious tradition, both traditional and critical, both female and male. This entails being cautious of any account that fails to recognize the complexity of both religion and women's (and children's) interests (Nussbaum, 2000a). 
According to (Nussbaum, 2000a) religious traditions have been powerful sources of protection for human rights, a commitment to justice and the energy of social change. She asserts "The liberty of religious belief, membership, and activity is among the central human capabilities, because the religious capabilities have multiple aspects" (Nussbaum, 2000a, p. 179). She has included them among the capabilities of the senses, imagination, and thought, and also in the category of affiliation (Canoy et al. 2010; Nussbaum, 2011). This strategy reflects her view that religion is an extremely important way of pursuing these general capability goals, but not the only one worthy of consideration.

According to Nussbaum (2000a, p. 179) "Religion has also been intimately and fruitfully bound up with other human capabilities, such as the capabilities of artistic, ethical, and intellectual expression. It has been a central locus of the moral education of the young, both in the family and in the larger community". She adds that religion has been a central vehicle of cultural continuity, and hence an inevitable support for other forms of human affiliation and interaction. She further emphasises that: "Religion is so important to people, such a major source of identity; there is also a strong argument from respect for persons that supplements these considerations of intrinsic value" (Nussbaum, 2000a, p. 180). She argues that religious capabilities must be respected but equally, that capabilities which are sometimes suppressed by religions must also be respected.

\section{Discussion:}

Clearly, religious perspectives have been thoroughly taken into consideration in the UDHR, UNCRC and the UN Guidelines. All these documents and the majority of religions have given a prominent position to vulnerable children. All four major religions in Sri Lanka emphasise the ethical responsibility of caring for a vulnerable child. Similarly, the UDHR recognizes this also, stating: "all children, whether born in or out of wedlock, shall enjoy the same social protection". Similarly, the UNCRC (United Nations, 1989) identifies that a child temporarily or permanently deprived of his or her family environment is entitled to special protection and assistance provided by the government.

In the Sri Lankan context, vulnerable children are categorized as orphaned, abandoned and destitute and are looked after in children's homes. The social, cultural, economic and environmental causes have given rise to a need for children's homes which inevitably bring together children from different religious beliefs and diverse cultural backgrounds. This multicultural environment illustrates the need to carefully consider the appropriate way to respond to cultural and religious diversity. The practical public education example of the children's home described in this paper has encouraged the children, through this experience, to see the relevance of multiple religions that enhance their capabilities to live in a multicultural world.

The PAR 2012 indicates that religious practices have been a common tradition in most children's homes. Its empirical and secondary data demonstrate that observing religion on a daily basis reminds the children of good manners, ethical conduct and disciplined life. Furthermore it is a reminder that religion concerns many other things such as faith, ritual practices, celebration, pleasure and contemplation. Furthermore, religious traditions have been identified as a powerful source of protection for human rights, of commitment to justice, and energy of social change. Religious capabilities have multiple aspects such as liberty of religious belief, membership and activity. Artistic, ethical and intellectual expressions fall under other human capabilities. Should children from a multicultural institutional care setting 
achieve their religious capabilities in addition to their human capabilities, their progress into the wider world is likely to be more successful.

\section{Recommendations}

Based on the findings of this paper, following recommendations are made to enhance children's rights through ensuring respect for all religions in multicultural children's homes environments.

- Provision of a religious observing space representing all religious affiliations of service providers and the service users of the children's home.

- Objectives of incorporating religious practices into children's homes should be:

To reform or to improve the religious capabilities of children.

$>$ To enhance the evolving capacities of children to become sensible and balanced citizens.

To inculcate moral values.

To educate, respecting the plurality and diversity of voices in each religious tradition.

- Consideration should be made of children's age and their interests when deciding the frequency and the amount of time devoted to religious practices.

- Mindfulness about varying capacities of children when observing religious traditions and activities.

- Provide and promote transparency to the general public of donations where funds/goods are used and where they are needed.

- Promotion of positive aspects and elimination of the negative aspects of the altruistic deeds such as the religious tradition of dane (meals and material donations) to children's homes. For e.g.

Accept meal donations in compliance with a weekly/fortnight menu table that indicates wholesome and nutritious meals in accordance with local dietary habits and relevant dietary standards, as well as with the children's religious beliefs. I.e. when providing meals, children's need to be attended to on a caseby-case basis considering the best interest of the child.

Accepting only the materials that have been identified as most needed for the maintenance aspects and the betterment of children's physical, mental and emotional growth.

Limit the number of people that visits children's home for offering dane to reduce the emotional impacts on children by them having to respond to the 'good deed'.

The time allocated for dane should be efficiently utilized to avoid disturbances to the children's and home's daily routine. 
- Educate public on the significance of their generous act by means of dane and make them aware of how they can contribute to overcome its negative aspects such as positioning the children as 'welfare cases'.

- When providing vocational training to institutionalized children, it is significant the need to consider the appropriate way to respond to cultural and religious diversity of the home and the diversity of environment where the home is situated - from the mainstream environment.

- Eliminate the religious conversions of children during institutionalization and be mindful of the fact that the objective of institutional care should be to provide emergency or temporary care until permanent alternative care provisions are sought.

\section{Conclusion}

It has been shown that there are inconsistencies among religions. However, in terms of children's rights and their needs, the four major religions that are practiced by Sri Lankans have similar perspectives. For instance, in Buddhism, children are the greatest treasure and in Hinduism, children are the greatest asset. According to Islam, children are a gift from the God, in Christianity; it is believed that children have great qualities that adults should incorporate into their lives. These religious perspectives demonstrate the significance of caring and protecting the children as a responsibility of all humankind that extends beyond parents bonds, family connections and cultural boundaries.

Religions dictate the significance of protecting the well-being of children and stress the negative impacts on the sustainable future of humankind if the present-day of children's lives are not properly preserved. Thus, it is the vast gap in economies, huge differences in literacy levels, diverse cultural backgrounds, varied political interests, enormous climatic changes and diverse religious traditions of different countries that cause disparate behaviours and lifestyles, religions have negligible effects on them.

When considering care for children from different cultural backgrounds and diverse religious affiliations, an approach that involves multiple religious perspectives becomes vital. This paper suggests that for such interventions, the capabilities approach is applicable as it values both human rights aspects and religious perspectives. The Capabilities Approach (Nussbaum, 2011) has been recognized by many social scientists and economists as a human development approach. It has demonstrated that, in terms of capabilities, different religions have similar perspectives. Thus, by providing an environment where children can function well while achieving their capabilities and enhancing their subjective and objective well-being, their needs can be catered for irrespective of their religious belief, and while safeguarding and respecting the right to practice a religion of their own choice.

\section{Acknowledgement}

This research is funded by the Australian Government's Endeavour Scholarships and Fellowships. The structure, ideas and philosophies presented in this paper draw on research under the supervision of Associate Professor Janet McIntyre, Dr Helen McLaren and Dr Leonie Solomons. Insights and feedback offered by Dr Greg Collings and Mr. Bruce Tanton were invaluable. The author would like to acknowledge their contributions. 


\section{References}

Ariyadasa, E. (2013). Life chances of children and young people in institutional care in Sri Lanka: A critical review of policy and governance with reference to case studies. Paper presented at the ISSS - 2013, Haiphong, Vietnam.

Ariyadasa, E. (2015). Poverty and Perception: Driving Sri Lankan children's homes at multiple levels. Paper presented at the KDU International Research Conference 2014, Colombo, Sri Lanka.

Ariyadasa, E., \& McIntyre-Mills, J. (2014a). Quality of Life of Sri Lankan Children: Participatory Action Research to Address the Governance Issues of Voluntary Children's Homes. Systemic Practice and Action Research, 9339, 1-26. doi: 10.1007/s11213-014-9339-7

Ariyadasa, E., \& McIntyre-Mills, J. (2014b). A Systemic Governance Approach to an Effective Re-integration Process for the Institutionalized Children in Sri Lanka: Application of Critical Systems Heuristics. Systemic Practice and Action Research, 9338, 1-23. doi: 10.1007/s11213-014-9338-8

Bible Hub (Producer). (2014). James 1:27. Retrieved from http://biblehub.com/james/127.htm

Canoy, M., Lerais, F., \& Schokkaert, E. (2010). Applying the capability approach to policymaking: The impact assessment of the EU-proposal on organ donation. The Journal of Socio-Economics, 39(3), 391-399. doi: 10.1016/j.socec.2009.11.002

Cook, P. (1996). Introduction. In H. Coward \& P. Cook (Eds.), Religious Dimensions of Child and Family Life: Reflections on the UN Convention on the Rights of the Child (pp. 1-9). University of Victoria: Centre for Studies in Religion and Society.

DPCCS. (2010). Statistical Report - 2010 (pp. 1-45). Colombo, Sri Lanka: Department of Probation and Child Care Services.

Fernando, C. G. (2006). Child Rights and Christian Teaching. In M. Seneviratne (Ed.), The Crime against Children: Commercial Sexual Exploitation of Children (pp. 231-233).

Gamage, D. T. (2015, April mid-month issue). Historical Developments of Buddhist Monastery Based Higher Education in Sri Lanka: 3rd Century BC to the 21st Century, Pahana, p. 36.

Gross, R. M. (1996). Child and Family in Buddhism. In H. C. P. Cook (Ed.), Religious Dimensions of Child and Family Life: Reflections on the UN Convention on the Rights of the Child (pp. 79-97). University of Victoria: Centre for Studies in Religion and Society.

Lababidy, L. (1996). Child and Family in Islam. In H. Coward \& P. Cook (Eds.), Religious Dimensions of Child and Family Life: Reflections on the UN Convention on the Rights of the Child (pp. 11-30). University of Victoria: Centre for Studies in Religion and Society.

Marsoof, S. (Producer). (2007). Adoption of children in Islam and the Muslim Law in Sri Lanka. Retrieved from https://www.academia.edu/9970099/Adoption_of_Children_in_Islam_and_the_Musli m_Law_of_Sri_Lanka

Nawaz, H. (1993). Towards Uniformity. In I. Jaising (Ed.), Justice for Women: Personal Laws, Women's Rights and Law Reform. Mapusa, Goa: The Other India Press.

Nussbaum, M. C. (2000a). Women and human development: The Capabilities Approach. Cambridge University Press, UK: Cambridge University Press.

Nussbaum, M. C. (2000b). Women and human development: The Capabilities Approach. New York: Cambridge University Press. 
Nussbaum, M. C. (2011). Creating Capabilities: The Human Development Approach: Harvard University Press.

Pereira, C. G. (2007). Kandy fights the Portuguese. Sri Lanka. Colombo, Sri Lanka: Vijitha Yapa Publications.

Ranganathananda, S. (2006). The Hindu Perspective. In M. Seneviratne (Ed.), The Crime against Children: Commercial Sexual Exploitation of Children (pp. 210-217): First Impressions.

Roberts, M. (2004). Sinhala Consciousness in the Kandyan Period: Sri Lanka. Colombo, Sri Lanka: Vijitha Yapa Publications.

Sarah, S. (Ed.) (2014) Stanford Encyclopaedia of Philosophy (Spring 2014 ed.). Centre for the Study of Language and Information: Stanford University.

Save the Children. (2005). Home Truths: Children Rights in Institutional Care in Sri Lanka. Colombo: Save the Children in Sri Lanka.

Shukri, M. A. M. (2006). Child Rights in Islam. In M. Seneviratne (Ed.), The Crime against Children: Commercial Sexual Exploitation of Children (pp. 218-227).

Sobitha, M. (2006). Child Rights: A Buddhist Perspective. In M. Seneviratne (Ed.), The Crime against Children: Commercial Sexual Exploitation of Children (pp. 228-230).

Thambiah, M. (2012a). Child sex abuse: More petitions, more predators, The Sunday Times, 12 May, Colombo, Sri Lanka, Viewed 30 May 2012.

Thambiah, M. (2012b). 4 children under 16 are raped daily, The Sunday Times, 24 June, Colombo, Sri Lanka, Viewed 1st July 2012.

Tamil Guardian. (2014). Root causes of the ethnic conflict in Sri Lanka. Retrieved 12 May, 2014, from http://www.tamilguardian.com/article

UNICEF. (2015). Fact Sheet: A summary of the rights under the Convention on the Rights of the Child: For every child Health, Education, Equality, Protection Advance Humanity. http://www.unicef.org/crc/files/Rights_overview.pdf

United Nations. (1948). United Nations Universal Declaration of Human Rights. New York: Office of the High Commissioner for Human Rights.

United Nations. (1989). Convention on the Rights of the Child A/RES/44/25 (pp. 1-15). New York: Office of the High Commissioner for Human Rights.

United Nations. (2010). Guidelines for the Alternative Care of Children A/RES/64/142 (pp. 123). New York: United nations General Assembly.

War Child. (2014). Where we work: Sri Lanka. Retrieved 10 May, 2014, from http://www.warchildholland.org/sri-lanka

Wicremasekera, C. (2004). Kandy at War. Colombo, Sri Lanka: Vijitha Yapa Publications. 